\title{
The effects of resveratrol on human health
}

\author{
Resveratrolün insan sağlı̆̆ üzerine etkileri
}

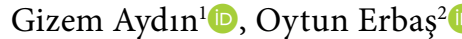 \\ ${ }^{1}$ Okan University Institute of Health Sciences, Istanbul, Turkey \\ ${ }^{2}$ Department of Physiology, Istanbul Bilim University Faculty of Medicine, Istanbul, Turkey
}

\begin{abstract}
Resveratrol is a phytochemical found in about 72 plants in nature. Among them, Polygonum cuspidatum is the most important, and is especially abundant in the skin of colorful grape varieties. Resveratrol is used in the prevention and treatment of various diseases. With its polyphenolic structure, it has antioxidant activity and can reduce the risk of heart disease by preventing platelet aggregation and LDL oxidation. It is also known to prevent cell death. In addition, some studies have demonstrated its positive effects on Alzheimer's, diabetes, obesity, and cancer. Since the scientific data in humans is limited, studies on the effects on physiological and pathological conditions and potential protective effects against diseases are still ongoing. This article examines and reviews the results of studies on the protective effects of resveratrol on the body and tissues.
\end{abstract}

Keywords: Alzheimer's disease, cancer, cardiovascular diseases, grape.

\section{$\ddot{z} z$}

Resveratrol doğada yaklaşık olarak 72 bitkide bulunun bir fitokimyasaldır. En önemlisi Polygonum cuspidatum'dur ve özellikle renkli üzüm çeşitlerinin kabuk kısmında yüksek miktarda bulunmaktadır. Resveratrol, çeşitli hastalıkların oluşumunu önlemede ve tedavisinde kullanılmaktadır. Polifenolik yapıda olmasıyla antioksidan aktiviteye sahip olup, trombosit kümeleşmesini ve LDL oksidasyonunu önleyerek kalp hastalıkları riskini azaltabilmektedir. Buna bağlı olarak hücre ölümünü önlediği de bilinmektedir. Ayrıca bazı çalışmalarda; Alzheimer, diyabet, obezite ve kanser hastalığı üzerinde olumlu etkiler gösterilmektedir. Bilimsel çalışma verileri insanlar üzerinde yetersiz olduğundan dolayı, fizyolojik ve patolojik durumlardaki etkiler ve hastalıklardaki olası koruyucu etkileri konusunda çalışmalar halen devam etmektedir. Bu makale, resveratrolün vücuttaki ve dokular üzerindeki koruyucu etkilerine dair çalışma sonuçları incelenip derlenerek ele alınmıştır.

Anahtar sözcükler: Alzheimer hastalığı, kanser, kardiyovasküler hastalıklar, üzüm.

Resveratrol was first isolated from the white hellebore plant (Veratrum grandiflorum O. LOES) in 1940 and its health effects have been investigated by Chinese and Japanese scientists for a long time. Resveratrol (trans-3,5,4'trihydroxystilbene) is a polyphenolic natural phytoalexin that forms a resistance mechanism against injury, ultraviolet (UV) rays, bacterial and fungal infections and can be obtained from many plants, especially black grapes. ${ }^{[1]}$ In China and Japan, resveratrol is derived from the roots of the "Polygonum cuspidatum" plant known as "kojo-kon" and is used in the treatment of many diseases such as hypertension, vascular occlusion, skin inflammation, and allergies. ${ }^{[2]}$

Nowadays, 72 plants have been determined to contain resveratrol. While Polygonum cuspidatum is the best source of resveratrol, it is also found in plants and fruits such as grapes, peanuts, hazelnuts, wine, eucalyptus, spruce, lily, vine leaves, blueberries, plums, mulberries, cherries, carob, and lemon. ${ }^{[3]}$ It is suggested that the resveratrol found in grapes and wine has contributed to the 
"French paradox" (the epidemiologically lower incidence of cardiovascular disease in the French population due to red wine consumption). ${ }^{[1]}$

Due to resveratrol's resistance to heat, the "trans" form is actively preserved in many foods, it is digested immediately after oral consumption and is rapidly absorbed into circulation. ${ }^{[3]}$

The health effects of resveratrol occur through multiple mechanisms. This article investigates the results of anti-carcinogenic, anti-inflammatory, anti-diabetic, antioxidant, life-extending, vasodilating, and cardioprotective effects of resveratrol.

\section{BIOSYNTHESIS AND METABOLISM OF RESVERATROL}

Resveratrol consists of a multi-step reaction starting with phenylalanine. In the first step, phenylalanine is converted to cinnamic acid through deamination catalyzed by ammonia lyase enzyme. Cinnamic acid is converted to 4-hydroxylase, which is converted to 4-coumaric acid with $p$-hydroxylation reactions. Coenzyme A $(\mathrm{CoA})$ is converted to is converted to its ester form with 4-coumarate. With the Co-A unit of 4-coumaril and stilbene synthase enzyme, resveratrol is formed, if the enzyme is absent, flavonoid forms. ${ }^{[4]}$

The majority of resveratrol is absorbed in the jejunum, and a smaller portion in the ileum. Most of resveratrol is transported to the basolateral side and is conjugated to its glucuronide and sulfate forms. All perfused resveratrol and only $6 \%$ of conjugates can penetrate the intestinal epithelium. Resveratrol is found in dietary products in "cis" and "trans" forms. Its glycolyzed form is 3-O- $\beta$-D-glucoside. Glycosylation prevents enzymatic oxidation, preserves its biological efficacy, and increases the bioavailability of resveratrol. Since intestinal cells can only absorb non-glycated resveratrol, glycosidases are necessary in the process of absorption. ${ }^{[5]}$

Orally consumed resveratrol attains its peak plasma levels within 30-60 minutes and can accumulate in organs such as the heart, liver, and kidneys, and is metabolized. ${ }^{[6,7]}$ It often turns into glucuronide and sulfate metabolites in the liver and duodenum. ${ }^{[5]}$
One experimental study on rodents observed that resveratrol achieved peak levels in 60 minutes in the plasma and kidneys, 30 minutes in the liver, and 120 minutes in the heart. ${ }^{[8]}$

Resveratrol enters the cell by binding to serum proteins, fatty acids, and lipoproteins. Resveratrol, which is mostly carried by lipoproteins, combines with LDL and enters liver cells via LDL receptors. ${ }^{[9]}$ Resveratrol's absorption and intracellular transport occurs in a short period of time and is generally eliminated through urine. ${ }^{[8]}$

One study made hematological, biochemical, and chemical comparisons of levels of resveratrol that was consumed daily. Subjects were administered daily 0.5/1.0/2.5 and $5.0 \mathrm{~g}$ of resveratrol daily for 29 days and no major side effects were observed. The most common side effect among these results was gastrointestinal complaints including abdominal pain, constipation, and nausea one hour after capsule intake in subjects receiving resveratrol over $1 \mathrm{~g}$ which continued throughout the day. Therefore, safe dosage of daily resveratrol should not exceed $1 \mathrm{~g} .{ }^{[10]}$ Another study stated that the effects of resveratrol of over $1 \mathrm{~g}$ may affect drug metabolism and enzymatic activities. ${ }^{[11]}$

\section{EFFECTS OF RESVERATROL ON HEALTH}

\section{Antioxidant Effects}

The natural polyphenol, resveratrol, is said to show free radical scavenging activity. By scavenging $\mathrm{OH}$ and $\mathrm{O}_{2}$ - radicals, it can eliminate lipid peroxidation caused by hydroxide radicals and can also prevent DNA damage induced by hydrogen peroxide and hydroxide. ${ }^{[1]}$

Resveratrol is said to be 20 times more effective than vitamin $C$ and 50 times more effective than vitamin $\mathrm{E}$ in preventing lipid peroxidation and also strengthens immunity. ${ }^{[3]}$

Recent studies have found that resveratrol increased iNOS expression that induces nitric oxide (NO) synthesis, and its protective effects against infection similar to nitric oxide, and antithrombotic and vasodilator properties have been demonstrated. ${ }^{[12]}$ It has been mentioned that when nitric oxide levels increase, lactate dehydrogenase activity indicating cellular damage 
reduced according to dosage. ${ }^{[13]}$ Following local brain ischemia associated with middle cerebral artery occlusion, exogenous intake of resveratrol was shown to reduce area of occlusion due to antioxidant properties. ${ }^{[14]}$

Resveratrol is effective on cellular antioxidant system activity. One study on mice with activated oxidative stress indicated that resveratrol regulated detoxification mechanisms, especially by increasing levels of catalase, superoxide dismutase, glutathione reductase, NADPH quinone oxidoreductase, and glutathione $\mathrm{S}$ transferase enzymes and decreased oxidative stress. ${ }^{[15]}$

\section{Anti-Cancer Effects}

While the effects of resveratrol on health has been shown in many fields, its anticancer properties, and regulatory effect on carcinogenesis in many cellular events have been demonstrated. It has been suggested that resveratrol, by directly binding to DNA and RNA, activates antioxidant enzymes, prevents inflammation, and stimulates kinases which control DNA damage control on genetic integrity specific to malignant cells. ${ }^{[16]}$

Resveratrol's endeavors to prevent and treat cancer can occur at specific stages of carcinogenesis, such as onset and progression. It inhibits the specific isoforms of cytochrome P450 enzymes, and prevents the initiation of carcinogenesis in human tumor cells, as it blocks metabolic activation following carcinogens. Resveratrol can also protect against cancer by inducing the phase II metabolism of carcinogens, thereby speeding up their excretion from the body. ${ }^{[17]}$

One study, that showed the significance of cyclooxygenase- 1 in regulating angiogenesis in vascular endothelial cells, found that $100 \mathrm{mcg} / \mathrm{mL}$ resveratrol had effect on arachidonic acid, and inhibited cyclooxygenase enzyme, which causes prostaglandin synthesis and plays a role in tumor formation, at rates of $98 \%$, therefore halting cell growth, or proliferation. ${ }^{[3]}$ The mechanism involving anticancer properties in resveratrol includes induction of apoptosis, inhibition of proliferation, cell cycle arrest, and inhibition of angiogenesis. ${ }^{[17]}$

Resveratrol prevents proliferation and induces apoptosis in various types of cancer including leukemia, breast, prostate, pancreatic, hepatocellular, and colorectal cancer. ${ }^{[17]}$ Tang et al. ${ }^{[18]}$ conducted a study on tumor-induced mice and observed that administration of twice daily $5 \mu \mathrm{M}, 10 \mu \mathrm{M}$, or $25 \mu \mathrm{M}$ doses of resveratrol for 18 weeks reduced number of tumors at rates of $50 \%, 63 \%$, and $88 \%$, respectively. Carbo et al. ${ }^{[19]}$ found that resveratrol prevented lesion formation and reduced tumor formation in skin in cancerinduced mice.

One study conducted in Switzerland showed that diet rich in lignan, quercetin, and resveratrol may be a protective factor against the development of esophageal cancer. ${ }^{[20]}$

Resveratrol reduces cancer cell formation in several different human cancers such as breast cancer, pancreatic cancer, lung cancer, stomach cancer, melanoma, and leukemia. Studies have shown that resveratrol inhibits abnormal cell proliferation in colon cancer models, and it has been reported that it can reduce gene expression of Myc, beta catenine, and cyclin D in human colon adenoma cells. ${ }^{[1]}$

Resveratrol inhibits tumors in human hepatocellular carcinoma by suppressing various signal transduction pathways, including mitogen active protein kinase, nuclear factor kappa B (NF- $\mathrm{B})$, matrix metalloproteinase-9 (MMP-9), vascular endothelial growth factor, and expression of AP-1. Similarly, it inhibits gastric adenocarcinoma cells by modifying cell proliferation and apoptosis through different mechanisms such as cell cycle regulatory proteins, caspase- 3 , and caspase- 9 activity. ${ }^{[1]}$

Studies have reported that resveratrol prevents the development of Helicobacter pylori, a bacterial organism that causes ulcer, gastritis, and stomach cancer, and also prevented the growth of breast cancer cells. It is said to destroy androgens in prostate cancer cells and metastasis of cancer cells in bone. ${ }^{[3]}$

Resveratrol has also been included in research on, not only its anti-cancer properties but also increasing the cytotoxic effects and reducing systemic side effects of chemotherapeutic drugs that. A study conducted among these studies states that resveratrol increases the cytotoxic effect of cisplatin in colorectal cancer cells. ${ }^{[21]}$ 


\section{Obesity}

Resveratrol inhibits adipogenesis, lowering lipid accumulation and increasing lipolysis of mature adipocytes. One study reported that $0.04 \%$ resveratrol supplementation in mice that were fed high-calorie diet containing 60\% fat increased lifespan and significantly reduced weight gain by $48 \%$. Therefore, it is suggested that resveratrol prevents visceral adipogenesis. ${ }^{[22]}$

In addition, $150 \mathrm{mg} /$ day trans-resveratrol regimen for 30 days was shown to mimic the effect of calorie restriction, and therefore help regulate obesity and other metabolic syndromes. ${ }^{[23]}$ Similarly, although resveratrol did not have a significant effect on lifespan in non-obese mice, it was said that it may delay occurrence of age-related abnormalities. This shows that resveratrol may be beneficial against the adverse metabolic effects of obesity. In non-human primates, resveratrol was shown to suppress body mass gain, metabolic ratios, and total energy consumption, and increase fat mobilization. ${ }^{[17]}$ Since resveratrol activates AMPK (Adenosine monophosphate protein kinase) and is involved in AMPK energy balance regulation and mitochondrial biogenesis, AMPK has been shown to be a possible mechanism by which resveratrol protects against metabolic dysfunction. ${ }^{[24]}$

Although the anti-obesity mechanism of resveratrol is not fully understood, its effect on various metabolic pathways such as adipogenesis, lipogenesis, lipolysis, thermogenesis, and fatty acid oxidation have been discussed. Resveratrol has been shown to potentially inhibit obesity by preventing preadipocyte differentiation, reducing adipocyte proliferation, inducing adipocyte apoptosis, reducing lipogenesis, and promoting lipolysis and $\beta$-oxidation of fatty acids. All of these effects of resveratrol are said to be associated with AMPK, sirtuin (SIRT 1), and peroxisome proliferator-activated receptor gamma coactivator 1-alpha (PGC-1 $\alpha$ ), which are the main regulators of adipogenesis, lipogenesis and fatty acids $\beta$-oxidation. ${ }^{[17]}$

One study reported resveratrol improved glucose tolerance by increasing insulin sensitivity in mice fed high fat diet and protected mice against the development of obesity. ${ }^{[17]}$

Despite the promising effects of resveratrol on obesity in animal models, the systematic review of nine randomized controlled trials on the effects of resveratrol on obesity in humans provided limited evidence for the use of resveratrol in obesity and weight management. Most studies did not observe a reduction in body weight after treatment with resveratrol for a period of 4-12 weeks in obese and nonobese people. In the only study reporting a clear beneficial effect on body weight, $500 \mathrm{mg}$ resveratrol was administered three times a day for 4 weeks in obese patients with metabolic syndrome. ${ }^{[25]}$ Therefore, it can be concluded that resveratrol may require a minimum of 12 weeks to reveal its effects of obesity in humans. Further human studies are required in order to confirm the effects of resveratrol, which may be provided by ongoing clinical trials. ${ }^{[26]}$

\section{Diabetes}

Diabetes is a chronic metabolic disease associated with inflammation and oxidative stress. Resveratrol may reduce the development of diabetic complications due to its anti-inflammatory and antioxidant effects. ${ }^{[27]}$

The most recent experimental data has reported that resveratrol may be beneficial in protecting against diabetes and alleviating some diabetic complications. It was indicated that resveratrol improved metabolic parameters, decreased plasma glucose and triglyceride concentrations, and reduced the effect of insulinemia in diabetes-induced rats. It was also reported that it may prevent oxidative stress-related nephropathy caused by diabetic hyperglycemia. ${ }^{[28]}$

Preclinical data showed that resveratrol may be helpful in management of diabetes by improving insulin resistance and problematic insulin signalization and preventing pancreas beta cell apoptosis and dysfunction. ${ }^{[27]}$

In diabetic animal models, resveratrol prevented hyperglycemia by increasing glucose uptake and caveolar (protrusion on the cell membrane) of the diabetic myocardium of GLUT4. Resveratrol improved glucose tolerance and reduces the expression of advanced glycation end products (AGEs) receptors in diabetic rat liver and kidneys. ${ }^{[29]}$ Resveratrol increased the levels of antioxidant enzymes such as SOD, catalase, and glutathione peroxidase in diabetic 
animals, while preventing the production of reactive nitrogen species such as ROS and superoxide anion, hydroxyl radical, hydrogen peroxide, and malondialdehyde. Resveratrol was also shown to inhibit proinflammatory signaling, NF- $\mathrm{KB}$ and reduce the production of inflammatory cytokines such as tumor necrosis factor alpha (TNF- $\alpha$ ), IL-1B, IL-4, and IL-6. In addition, resveratrol, dependent on AMPK, increased insulin sensitivity, glucose tolerance, and mitochondrial biogenesis. ${ }^{[30]}$

While the benefits of resveratrol on glycemic control was demonstrated in some human studies, other studies were unable to achieve significant effects. In patients with Type 2 diabetes who were using metformin or glibenclamide, $250 \mathrm{mg} /$ day resveratrol was given in addition for three months, and when compared to those who only used metformin or glibenclamide, resveratrol was not observed to significantly improve glycemic parameters. ${ }^{[31]}$ Movahed et al. ${ }^{[32]}$ also reported that resveratrol, given as $1 \mathrm{~g} /$ day for 45 days, reduced fasting blood sugar, $\mathrm{HbA} 1 \mathrm{c}$, and systolic blood pressure.

It was also mentioned that a lower dose resveratrol regimen of $5 \mathrm{mg} /$ day for 28 days also decreased HBA1C and systolic blood pressure and increased insulin sensitivity, but did not affect the homeostatic model of insulin resistance. ${ }^{[3]}$

Thazhath et al. ${ }^{[33]}$ conducted an RCT on controlled type 2 diabetes in which $500 \mathrm{mg}$ resveratrol twice daily was added to diet for five weeks, and reported that resveratrol did not significantly improve glycemic control. Another study did not find significant difference between resveratrol and placebo group in terms of fasting glucose level, postprandial glucose level, $\mathrm{HbA} 1 \mathrm{c}$, gastric emptying, and glucagonlike peptide 1 secretion. ${ }^{[34]}$ Similarly, resveratrol did not improve metabolic parameters in another six-month regimen. Therefore, the effect of resveratrol on human diabetes is not completely understood. ${ }^{[35]}$

\section{Cardiac Health}

The cardioprotective effects of resveratrol initially began with the observation of the French paradox, in which mortality related to coronary heart diseases appeared to significantly diminish in the French population, despite harmful risk factors such as high consumption of cholesterol, saturated fat, and smoking. The first efforts to understand the French paradox was by Renaud in 1992, who presented a negative correlation between drinking wine and cardiovascular morbidity. The relatively high intake of wine in the French population led Renaud to believe that the daily 1-2.5 mg resveratrol by drinking wine eliminated the harmful effects of dairy fat intake. ${ }^{[17]}$

Resveratrol reduces lipid peroxidation as well as the production of reactive oxygen species. Resveratrol decreases inflammation by inhibiting prostaglandin production, cyclogenase- 2 and $\mathrm{NF}-\mathrm{\kappa B}$ activity, providing cardioprotective and anti-cancer effects. ${ }^{[17]}$

Many studies have shown the beneficial effects of resveratrol on vascular function, platelet aggregation, atherosclerosis, oxidative stress, cardiac hypertrophy and ischemic reperfusion injury. Resveratrol, a polyphenol, plays the role of a good agent in several aspects of atherogenesis (fat accumulation and oxidation of low lipoproteins, platelet aggregation, LDL). Another important point is that it protects against various diseases such as myocardial ischemic reperfusion injury and ventricular arrhythmia by eliminating apoptotic cell death. ${ }^{[36]}$

Resveratrol research on the prevention of primary and secondary cardiovascular diseases seem promising, but small sample size $(n=75)$ and short follow-up (one year) limit clinical significance. In one study, 75 subjects were randomly divided into three groups. The first group was given grape extract capsules containing resveratrol $(8.1 \mathrm{mg} / \mathrm{day}$ for the first 6 months and $16.2 \mathrm{mg} /$ day for the next 6 months), while the second group was given grape extract capsules without resveratrol and the third group was given placebo capsules. Compared to the placebo-only and grape extract group, the resveratrol group showed significant decrease in anti-inflammatory adiponectin and thrombogenic plasminogen activator inhibitor-1. Therefore, resveratrol reveals cardioprotective effects by improving anti-inflammatory response and preventing atherothrombotic signaling. ${ }^{[17]}$

Existing guidelines may define resveratrol as primary protection against cardiovascular disease, as it provides additional benefits with other 
phenols in grape extract in those at high risk of cardiovascular diseases. ${ }^{[17]}$

The protective mechanisms of resveratrol on cardiac health include:

\section{Vascular compliance and blood pressure}

Intake of $2.5 \mathrm{mg} / \mathrm{kg} /$ day of resveratrol over 10 weeks increased small mesenteric artery compliance and reduced wall stiffness in normotensive rats. Resveratrol therapy weakened arterial compliance in hypertensive rats by inhibiting extracellular kinase-regulated signaling. ${ }^{[37]}$

Resveratrol had no effect on low blood pressure in low doses, while at higher doses of $200 \mathrm{mg} / \mathrm{kg} /$ day, resveratrol together with hydralazine was more effective in lowering blood pressure in naturally hypertensive rats compared to resveratrol or hydralazine alone. ${ }^{[17]}$

Resveratrol had no effect on blood pressure at low doses $(2.5 \mathrm{mg} / \mathrm{kg} /$ day for 10 weeks); high-dose resveratrol of $200 \mathrm{mg} / \mathrm{kg} /$ day lowered systolic blood pressure in hypertensive rats. Combination of low-dose resveratrol $(2.5 \mathrm{mg} / \mathrm{kg} /$ day $)$ with hydralazine (25 mg/kg/day) was more effective than resveratrol or hydralazine alone in lowering blood pressure in hypertensive rats. Likewise, a meta-analysis of six randomized control studies in humans showed that resveratrol intake of $150 \mathrm{mg} /$ day reduced systolic blood pressure, but not at doses any lower. ${ }^{[17]}$

To date, there are few studies on the effect of resveratrol on blood pressure in humans. In a randomized double-blind placebo-controlled study, high-dose resveratrol (125 mg twice daily) was shown to reduce both systolic and diastolic blood pressure, while lower dose of $50 \mathrm{mg}$ twice daily had no effect. ${ }^{[38]}$

\section{Platelet aggregation}

Aside from other factors, activation of platelet aggregation is an important contribution to atherothrombosis development. As a response to rupture of an unstable atherosclerotic plaque, platelets become activated and result in formation of thrombosis. Plaque rupture and resulting thrombosis may enter systemic circulation and cause blood vessel occlusion, restricting supply to organs such as the heart (myocardial infarction) or brain (stroke). For this reason, inhibition of platelet activity is a vital strategy to prevent this thrombotic consequence. ${ }^{[39]}$

Resveratrol has been shown to inhibit platelet aggregation in both human and animal studies. In addition, an in vitro study of resveratrol $(50 \mathrm{mcg} / \mathrm{mL})$ indicated that it inhibited platelet aggregation caused by collagen, epinephrine, and thromboxane, and these effects were attributed to cyclooxygenase (COX-1) suppression on the arachidonic acid pathway. ${ }^{[17]}$

\section{Ischemic reperfusion injury}

In neonatal cardiomyocytes exposed to two-hour ischemia and four-hour symmetric reperfusion through simulation, resveratrol alleviated ischemic reperfusion injury by lowering intracellular calcium, prevented apoptosis, and modified scavenging enzyme activities of reactive oxygen species such as superoxide dismutase. ${ }^{[40]}$

The other mechanism to unravel the antioxidant effects of resveratrol was reportedly modulation of mitochondrial membrane permeability transition pore (MPTP) and induction of adenosine monophosphate (AMP) and AMPK activity and nitric oxide synthase. ${ }^{[41]}$

Resveratrol activation in cardiomyocytes protects against hypoxia-reoxygenation injury by regulation of the increased SIRT1. SIRT1 is a NAD+dependent protein deacetylase that activates PGC1a through deacetylation, and increasing mitochondrial function and oxidative capacity. ${ }^{[17]}$

In an animal model of ischemic reperfusion injury, resveratrol was shown to improve cardiac function, oxidative stress and inflammation markers such as TNF- $\alpha$, interleukin-1- $\beta$, and myeloperoxidase activity. ${ }^{[17]}$ One study conducted with relatively lower doses $(2.5-5 \mathrm{mg} / \mathrm{kg} /$ day) found that resveratrol made the heart resistant to ischemic reperfusion. ${ }^{[42]}$

\section{Atherosclerosis}

Resveratrol alters vascular function, reduces lipid accumulation, and modulates gene expression related to lipogenesis and lipolysis. Resveratrol also inhibits oxidized LDL-induced apoptosis in vascular endothelial cells. Polyphenols such as resveratrol oxidize LDL by inhibiting cellular oxygenases such as 15-lipoxygenase, cytochrome p450, nicotinamide adenine dinucleotide phosphate-reduced oxidase, and myeloperoxidase 
or stimulating cellular antioxidants such as the glutathione system. ${ }^{[43]}$

Arichi et al. ${ }^{[44]}$ and Kimura et al. ${ }^{[45]}$ conducted studies on rats and concluded that resveratrol prevented liver fattening. Resveratrol also reduced triacylglycerol levels and protected the liver against lipid peroxidation. ${ }^{[3]}$

\section{Effects on Performance}

Energy production is essential to performance, and both skeletal muscle mass and number of mitochondria, known as the powerhouse of the cell, are highly significant. The number of mitochondria vary according to exercise or against other stimulants, and this is described as mitochondrial biogenesis. Exercise has been shown to increase mitochondrial biogenesis by $40 \%$. However, according to in vitro studies, resveratrol has also been observed to improve mitochondrial function and biogenesis in skeletal muscle and the liver. ${ }^{[46]}$

Like the effect produced by exercise, resveratrol also reportedly increases fatty acid oxidation and exercise performance, while supplementation strengthens the effect of exercise, ultimately suggesting its use as an ergogenic supportive product. ${ }^{[46]}$

Other studies have also demonstrated resveratrol and diet caused increased exercise performance, dose-dependent decrease in parameters associated with fatigue induced by exercise (lactate, ammonia, creatinine kinase), increased oxygen consumption, and increased mRNA levels in enzymes related to mitochondrial functions in skeletal muscle, and according to these data, resveratrol has the potential to be used as an exercise performance-increasing agent. ${ }^{[46]}$

\section{Effects on Alzheimer's Disease}

Alzheimer's disease is a neurological disease characterized by impaired memory and multiple cognitive functions, presence of intracellular neurofibril balls and extracellular amyloid beta $(A \beta)$ peptides, synaptic insufficiency, and mitochondrial dysfunction. ${ }^{[3]}$

Resveratrol increases the activity of proteases without stopping $A \beta$ production and has a healing effect on Alzheimer's disease by stimulating intracellular destruction of $A \beta$. Other studies have led us to believe that people who drink red wine are at low risk of developing Alzheimer's disease. ${ }^{[3]}$

In one randomized placebo-controlled clinical study, in which resveratrol was initiated at $500 \mathrm{mg}$ daily dose for 52 weeks and later increased to $1000 \mathrm{mg}$ twice daily dose, it was reported that it was safe and well-tolerated by Alzheimer's patients. In that study, the resveratrol group had significant decreased levels of $A \beta$ in CSF and plasma compared to the placebo group. However, other significant biomarkers of Alzheimer's disease were unaffected. Therefore, the study concluded that it could not clearly demonstrate the effect of resveratrol on Alzheimer's disease. ${ }^{[47]}$

To the contrary, $200 \mathrm{mg} /$ day resveratrol for 26 weeks and $320 \mathrm{mg} /$ day quercetin supplementation (to improve bioavailability of resveratrol) improved memory performance of adults with healthy weights. ${ }^{[48]}$

\section{Conclusion}

Resveratrol is a significant polyphenolic compound in protecting health. Grapes are one of the most important food sources in nature. Adding resveratrol, which is highly concentrated in the skins of grapes, to daily nutrition has been shown by many studies to produce protective effects against several diseases. However, data from human studies are limited and therefore, further studies should be performed more frequently.

\section{Declaration of conflicting interests}

The authors declared no conflicts of interest with respect to the authorship and/or publication of this article.

\section{Funding}

The authors received no financial support for the research and/or authorship of this article.

\section{REFERENCES}

1. Nawaz W, Zhou Z, Deng S, Ma X, Ma X, Li C, et al. Therapeutic Versatility of Resveratrol Derivatives. Nutrients 2017;9. pii: E1188.

2. Pervaiz S. Resveratrol: from grapevines to mammalian biology. FASEB J 2003;17:1975-85.

3. Keskin N, Noyan T, Kunter B. Resveratrol ile üzümden gelen sağllk. Turkiye Klinikleri J Med Sci 2009;29:1273-9. 
4. Yurdakül Ö. Resveratrolün insan akciğer kanseri hücrelerinde (H1299) antioksidan etkisinin araştırılması [Yüksek Lisans Tezi], Antalya: Akdeniz Üniversitesi, Fen Bilimleri Enstitü; 2017.

5. Ndiaye M, Kumar R, Ahmad N. Resveratrol in cancer management: where are we and where we go from here? Ann N Y Acad Sci 2011;1215:144-9.

6. Walle $\mathrm{T}$, Hsieh F, DeLegge MH, Oatis JE Jr, Walle UK. High absorption but very low bioavailability of oral resveratrol in humans. Drug Metab Dispos 2004;32:1377-82.

7. Cottart $\mathrm{CH}$, Nivet-Antoine $\mathrm{V}$, Beaudeux JL. Review of recent data on the metabolism, biological effects, and toxicity of resveratrol in humans. Mol Nutr Food Res 2014;58:7-21.

8. Baltaci SB, Mogulkoc R, Baltaci AK. Resveratrol and exercise. Biomed Rep 2016;5:525-30.

9. Delmas D, Lin HY. Role of membrane dynamics processes and exogenous molecules in cellular resveratrol uptake: consequences in bioavailability and activities. Mol Nutr Food Res 2011;55:1142-53.

10. Brown VA, Patel KR, Viskaduraki M, Crowell JA, Perloff M, Booth TD, et al. Repeat dose study of the cancer chemopreventive agent resveratrol in healthy volunteers: safety, pharmacokinetics, and effect on the insulin-like growth factor axis. Cancer Res 2010;70:9003-11.

11. Chow HH, Garland LL, Hsu CH, Vining DR, Chew WM, Miller JA, et al. Resveratrol modulates drug- and carcinogen-metabolizing enzymes in a healthy volunteer study. Cancer Prev Res 2010;3:1168-75.

12. Naderali EK, Doyle PJ, Williams G. Resveratrol induces vasorelaxation of mesenteric and uterine arteries from female guinea-pigs. Clin Sci 2000;98:537-43.

13. Hung LM, Chen JK, Huang SS, Lee RS, Su MJ. Cardioprotective effect of resveratrol, a natural antioxidant derived from grapes. Cardiovasc Res 2000;47:549-55.

14. Huang SS, Tsai MC, Chih CL, Hung LM, Tsai SK. Resveratrol reduction of infarct size in Long-Evans rats subjected to focal cerebral ischemia. Life Sci 2001;69:1057-65.

15. Rubiolo JA, Mithieux G, Vega FV. Resveratrol protects primary rat hepatocytes against oxidative stress damage: activation of the Nrf2 transcription factor and augmented activities of antioxidant enzymes. Eur J Pharmacol 2008;591:66-72.

16. Shrotriya S, Agarwal R, Sclafani RA. A perspective on chemoprevention by resveratrol in head and neck squamous cell carcinoma. Adv Exp Med Biol 2015;815:333-48.

17. Akinwumi BC, Bordun KM, Anderson HD. Biological Activities of Stilbenoids. Int $\mathrm{J}$ Mol Sci 2018;19. pii: E792.

18. Jang M, Cai L, Slowing KV, Thomas CF, Beecher $\mathrm{CW}$, Fong $\mathrm{HH}$, et al. Cancer chemopreventive activity of resveratrol, a natural product derived from grapes. Science 1997;275:218-20.

19. Carbó N, Costelli P, Baccino FM, López-Soriano FJ, Argilés JM. Resveratrol, a natural product present in wine, decreases tumour growth in a rat tumour model. Biochem Biophys Res Commun 1999;254:739-43.

20. Lin Y, Yngve A, Lagergren J, Lu Y. A dietary pattern rich in lignans, quercetin and resveratrol decreases the risk of oesophageal cancer. Br J Nutr 2014;112:2002-9.

21. Yuan L, Zhang Y, Xia J, Liu B, Zhang Q, Liu J, et al. Resveratrol induces cell cycle arrest via a p53independent pathway in A549 cells. Mol Med Rep 2015;11:2459-64.

22. Baur JA, Pearson KJ, Price NL, Jamieson HA, Lerin C, Kalra A, et al. Resveratrol improves health and survival of mice on a high-calorie diet. Nature 2006;444:337-42.

23. Timmers S, Konings E, Bilet L, Houtkooper RH, van de Weijer T, Goossens GH, et al. Calorie restrictionlike effects of 30 days of resveratrol supplementation on energy metabolism and metabolic profile in obese humans. Cell Metab 2011;14:612-22.

24. Um JH, Park SJ, Kang $H$, Yang S, Foretz M, McBurney MW, et al. AMP-activated protein kinasedeficient mice are resistant to the metabolic effects of resveratrol. Diabetes 2010;59:554-63.

25. Um JH, Park SJ, Kang H, Yang S, Foretz M, McBurney MW, et al. AMP-activated protein kinasedeficient mice are resistant to the metabolic effects of resveratrol. Diabetes 2010;59:554-63.

26. Méndez-del Villar M, González-Ortiz M, MartínezAbundis E, Pérez-Rubio KG, Lizárraga-Valdez R. Effect of resveratrol administration on metabolic syndrome, insulin sensitivity, and insulin secretion. Metab Syndr Relat Disord 2014;12:497-501.

27. Szkudelski T, Szkudelska K. Resveratrol and diabetes: from animal to human studies. Biochim Biophys Acta 2015; 1852:1145-54.

28. Ergin K, Yaylalı A. Resveratrol ve etkileri üzerine bir gözden geçirme. SDÜ Tip Fakültesi Dergisi 2013;20:115-20.

29. Khazaei M, Karimi J, Sheikh N, Goodarzi MT, Saidijam M, Khodadadi I, et al. Effects of Resveratrol on Receptor for Advanced Glycation End Products (RAGE) Expression and Oxidative Stress in the Liver of Rats with Type 2 Diabetes. Phytother Res 2016;30:66-71.

30. Soufi FG, Mohammad-Nejad D, Ahmadieh H. Resveratrol improves diabetic retinopathy possibly through oxidative stress - nuclear factor $\mathrm{\kappa B}$ - apoptosis pathway. Pharmacol Rep 2012;64:1505-14.

31. Bhatt JK, Thomas S, Nanjan MJ. Resveratrol supplementation improves glycemic control in type 2 diabetes mellitus. Nutr Res 2012;32:537-41.

32. Movahed A, Nabipour I, Lieben Louis X, Thandapilly SJ, Yu L, Kalantarhormozi M, et al. Antihyperglycemic effects of short term resveratrol supplementation in 
type 2 diabetic patients. Evid Based Complement Alternat Med 2013;2013:851267.

33. Thazhath SS, Wu T, Bound MJ, Checklin HL, Standfield S, Jones $\mathrm{KL}$, et al. Administration of resveratrol for 5 wk has no effect on glucagon-like peptide 1 secretion, gastric emptying, or glycemic control in type 2 diabetes: a randomized controlled trial. Am J Clin Nutr 2016;103:66-70.

34. Thazhath SS, Wu T, Bound MJ, Checklin HL, Standfield S, Jones KL, et al. Administration of resveratrol for 5 wk has no effect on glucagon-like peptide 1 secretion, gastric emptying, or glycemic control in type 2 diabetes: a randomized controlled trial. Am J Clin Nutr 2016;103:66-70.

35. Bo S, Ponzo V, Ciccone G, Evangelista A, Saba F, Goitre I, et al. Six months of resveratrol supplementation has no measurable effect in type 2 diabetic patients. A randomized, double blind, placebo-controlled trial. Pharmacol Res 2016;111:896-905.

36. Petrovski G, Gurusamy N, Das DK. Resveratrol in cardiovascular health and disease. Ann N Y Acad Sci 2011;1215:22-33.

37. Behbahani J, Thandapilly SJ, Louis XL, Huang Y, Shao Z, Kopilas MA, et al. Resveratrol and small artery compliance and remodeling in the spontaneously hypertensive rat. Am J Hypertens 2010;23:1273-8.

38. Riche DM, Riche KD, Blackshear CT, McEwen CL, Sherman JJ, Wofford MR, et al. Pterostilbene on metabolic parameters: a randomized, double-blind, and placebo-controlled trial. Evid Based Complement Alternat Med 2014;2014:459165.

39. Silva MV, Dusse LM, Vieira LM, Carvalho Md. Platelet antiaggregants in primary and secondary prevention of atherothrombotic events. Arq Bras Cardiol 2013;100:e78-84.
40. Shen M, Wu RX, Zhao L, Li J, Guo HT, Fan R, et al. Resveratrol attenuates ischemia/reperfusion injury in neonatal cardiomyocytes and its underlying mechanism. PLoS One 2012;7:e51223.

41. Shen M, Jia GL, Wang YM, Ma H. Cardioprotective effect of resvaratrol pretreatment on myocardial ischemia-reperfusion induced injury in rats. Vascul Pharmacol 2006;45:122-6.

42. Das DK, Maulik N. Resveratrol in cardioprotection: a therapeutic promise of alternative medicine. Mol Interv 2006;6:36-47.

43. Bertelli AA, Das DK. Grapes, wines, resveratrol, and heart health. $\mathrm{J}$ Cardiovasc Pharmacol 2009;54:468-76.

44. Arichi H, Kimura Y, Okuda H, Baba K, Kozawa $\mathrm{M}$, Arichi S. Effects of stilbene components of the roots of Polygonum cuspidatum Sieb. et Zucc. on lipid metabolism. Chem Pharm Bull (Tokyo) 1982;30:1766-70.

45. Kimura Y, Ohminami H, Okuda H, Baba K, Kozawa $\mathrm{M}$, Arichi S. Effects of stilbene components of roots of Polygonum ssp. on liver injury in peroxidized oil-fed rats. Planta Med 1983;49:51-4.

46. Andaç Öztürk S. Farelerde resveratrol ile beslenmenin myogenin ve mTOR düzeyleri üzerine etkisi [Doktora Tezi]. Ankara: Başkent Üniversitesi, Sağlık Bilimleri Enstitü; 2016.

47. Turner RS, Thomas RG, Craft $\mathrm{S}$, van Dyck $\mathrm{CH}$, Mintzer J, Reynolds BA, et al. A randomized, doubleblind, placebo-controlled trial of resveratrol for Alzheimer disease. Neurology 2015;85:1383-91.

48. Witte AV, Kerti L, Margulies DS, Flöel A. Effects of resveratrol on memory performance, hippocampal functional connectivity, and glucose metabolism in healthy older adults. J Neurosci 2014;34:7862-70. 